\title{
PENGARUH PEMBERIAN BUAH PEPAYA (Carica papaya L.) TERHADAP KADAR KOLESTEROL LDL DAN KOLESTEROL HDL PADA TIKUS SPRAGUE DAWLEY DENGAN HIPERKOLESTEROLEMIA
}

\author{
Widitha Gustining Asmariani, Enny Probosari ${ }^{*}$ \\ Program Studi Ilmu Gizi Fakultas Kedokteran Universitas Diponegoro \\ Jl.Dr.Sutomo No.14, Semarang, Telp (024) 8453708, Email : gizifk@undip.ac.id
}

\begin{abstract}
Background: Increased LDL cholesterol concentrations and low plasma HDL cholesterol concentrations are wellestablished risk factors for cardiovascular disease. Diet modification is one of recommended theraphy to decrease LDL cholesterol level by increasing fiber intake from fruit. Papaya contains niacin, fiber, and antioxidant which can decrease LDL cholesterol level. It also contains quercetin to increase HDL cholesterol level. The aim of this study was to prove the effect of papaya of different dosages on LDL and HDL cholesterol of hypercholesterolemic rats. Methods: This research was true-experimental using pre-post test with control group design. Subjects were male Sprague Dowley rats, 7-8 weeks old, 100-200 grams weight, inducted hypercholesterolemia, given papaya diet using 5,4 gr, 7,2 gr, and 9,0 gr dosage for 4 weeks. LDL cholesterol and HDL cholesterol were measured by direct method using LDL-C Select (DiaSys) reagent and CHOP-PAP methods respectively. Normality of the data was tested by Shapiro Wilks test. Data were analyzed by paired t test continued with One Way Anova.and post-hoc LSD. Result: The study revealed that papaya of dosage 5,4 gr/day decreased LDL cholesterol ( $p<0,05)$ significantly from

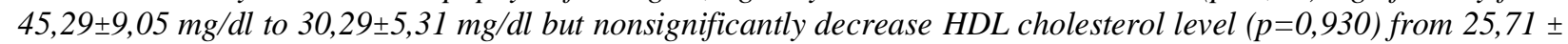
5,09 to 25,57 $\pm 3,59 \mathrm{mg} / \mathrm{dl}$ at the same dosage. Other dosage of 7,2 $\mathrm{mg} /$ day and 9,0 gr/day neither significantly decrease LDL cholesterol level nor increase HDL cholesterol level.

Conclusion: Papaya couldn't decreased LDL cholesterol and increased HDL cholesterol in hypercholesterolemic rats.
\end{abstract}

Keywords: papaya; LDL cholesterol; HDL cholesterol; hypercholesterolemic

\section{ABSTRAK}

Latar Belakang: Peningkatan kadar kolesterol LDL dan penurunan kadar kolesterol HDL dapat meningkatkan risiko penyakit kardiovaskuler. Pengaturan diet dengan mengkonsumsi buah kaya serat merupakan salah satu terapi yang disarankan untuk menurunkan kadar kolesterol LDL. Buah pepaya mengandung niasin, serat, dan antioksidan yang dapat menurunkan kadar kolesterol LDL serta quercetin untuk meningkatkan kadar kolesterol HDL. Penelitian ini bertujuan untuk mengetahui pengaruh pemberian buah pepaya terhadap kadar kolesterol LDL dan kolesterol HDL tikus hiperkolesterolemia.

Metode: Penelitian ini berjenis true-experimental dengan pre-post test with control group design. Subjek penelitian adalah tikus galur Sprague Dowley berumur 7-8 minggu, berat 100-200 gr, diinduksi hiperkolesterolemia, diberi buah pepaya dosis 5,4 gr, 7,2 gr, dan 9,0 per hari selama 4 minggu. Kadar kolesterol LDL dan kolesterol HDL diperiksa dengan metode direk menggunakan reagen LDL-C Select (DiaSys) dan CHOP-PAP. Normalitas data diuji dengan uji Shapiro Wilks. Data dianalisis dengan uji t berpasangan yang dilanjutkan uji One Way Anova dan posthoc LSD.

Hasil: Pemberian buah pepaya pada dosis 5,4 gr/hari dapat menurunkan kadar kolesterol LDL $(p<0,05)$ secara

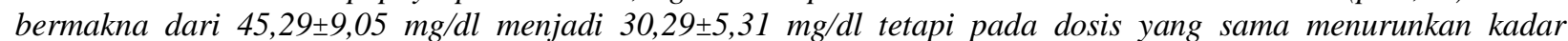
kolesterol HDL dari 25,71 \pm 5,09 menjadi 25,57 \pm 3,59 mg/dl. Dosis pemberian lain yaitu 7,2 gr dan 9,0 gr per hari tidak memberikan pengaruh bermakna terhadap penurunan kadar kolesterol LDL maupun peningkatan kolesterol $H D L$.

Simpulan: Buah pepaya tidak dapat menurunkan kadar kolesterol LDL dan meningkatkan kadar kolesterol HDL pada tikus hiperkolesterolemia.

Kata kunci: buah pepaya; kolesterol LDL; kolesterol HDL; hiperkolesterolemia

\section{PENDAHULUAN}

Penyakit kardiovaskuler (PKV) terutama penyakit jantung merupakan penyebab kematian utama di dunia. Menurut WHO, 60\% penyebab kematian penyakit jantung disebabkan penyakit jantung koroner (PJK) dan pada tahun 2008 tercatat 17,3 juta kematian karena PKV dengan 7,3 juta diantaranya karena PJK. ${ }^{1}$ Laporan Sakernas

${ }^{*}$ Penulis Penanggungjawab 
tahun 2009 menunjukkan PJK merupakan penyebab $23,6 \%$ kematian orang Indonesia dan penyebab utama kematian dini pada $40 \%$ kematian laki-laki usia menengah. ${ }^{2}$ PJK dipicu oleh banyak faktor, salah satunya hiperkolesterolemia. ${ }^{1,3}$

Hiperkolesterolemia merupakan kondisi dimana kadar kolesterol total dalam darah meningkat hingga $\geq 240 \mathrm{mg} / \mathrm{dl}$ atau melebihi batas normal $(120-200 \mathrm{mg} / \mathrm{dl})$ yang disebabkan karena gangguan metabolisme lemak. ${ }^{4}$ Hiperkolesterolemia juga berkaitan dengan peningkatan kadar Low Density Lipoprotein (LDL) dan penurunan kadar High Density Lipoprotein (HDL). Oleh karena itu, untuk menghindarinya dibutuhkan pengendalian kadar kolesterol LDL dan kolesterol HDL secara tepat salah satunya melalui pengaturan diet yang merupakan alternatif terapi yang lebih aman dari terapi obat. Pengaturan diet yang disarankan adalah dengan mengurangi konsumsi lemak total dan lemak jenuh serta meningkatkan asupan sayuran dan buah kaya serat. $^{3,5}$

Buah pepaya (Carica papaya L.) memiliki efek antihiperlipidemia melalui aktivitas berbagai macam senyawa biologis yang terkandung di dalamnya seperti niasin, serat, dan antioksidan seperti vitamin C, dan flavonoid. Antioksidan berperan memerangi radikal bebas dan menjaga kesehatan sistem kardiovaskular dengan memperbaiki profil lipid darah. ${ }^{6,7}$ Buah pepaya matang memiliki kandungan vitamin $\mathrm{C}$ sekitar 61,8 mg dalam setiap 100 gram bagian yang dapat dimakan. ${ }^{8}$ Kandungan quercetin $(2 \mathrm{mg} / 100$ gr $)$ dalam pepaya menghambat oksidasi kolesterol LDL dan mencegah pembentukan radikal bebas serta mampu meningkatkan kadar kolesterol HDL. ${ }^{8,9}$ Pepaya mengandung vitamin $\mathrm{B}_{3}$ (niasin) sebanyak $0,338 \mathrm{mg} / 100$ gr yang dapat menurunkan produksi VLDL di hati sehingga produksi kolesterol LDL menurun. ${ }^{8,10}$ Kandungan lain yang bermanfaat adalah pektin dalam pepaya. ${ }^{11}$ Serat larut air jenis pektin dapat menurunkan kadar kolesterol dengan mengikat asam empedu dan kolesterol di lumen usus dan mengekskresikannya bersama feses sehingga kadar kolesterol dalam tubuh menurun. ${ }^{12}$

Penelitian terdahulu yang dilakukan pada Rattus norvegicus $L$. yang diberi makanan tinggi kolesterol menunjukkan bahwa pemberian ekstrak buah pepaya hijau sebanyak 25,50 , dan $100 \mathrm{mg} / \mathrm{kg}$ berat badan selama 30 hari memiliki efek antihiperlipidemia dengan menurunkan kadar kolesterol LDL, dan meningkatkan kadar kolesterol HDL secara signifikan. ${ }^{13}$
Penelitian tentang buah pepaya matang tanpa kulit dan biji terhadap kadar kolesterol LDL dan kolesterol HDL belum pernah dilakukan. Secara khusus penelitian ini bertujuan untuk mendeskripsikan perubahan kadar kolesterol LDL dan kolesterol HDL darah tikus Sprague Dawley sebelum dan setelah pemberian buah papaya (Carica papaya L) selama 4 minggu serta menganalisis perbedaan perubahan kadar kolesterol LDL dan kolesterol HDL antar kelompok perlakuan.

\section{METODE PENELITIAN}

Penelitian ini berjenis true eksperimental dengan pre-post test with control group design. Variabel bebas pada penelitian ini adalah pemberian buah pepaya dalam berbagai dosis sedangkan variabel terikatnya adalah perubahan kadar kolesterol LDL dan kolesterol HDL. Penelitian dilakukan di Laboratorium Jurusan Biologi FMIPA Universitas Negeri Semarang. Subjek penelitian adalah tikus jantan galur Sprague Dawley umur 7-8 minggu dengan berat badan 100200 gram yang diperoleh dari Fakultas Farmasi Universitas Gajah Mada Yogyakarta. Proses aklimatisasi dilakukan selama 1 minggu menggunakan kandang individu dan mendapat pakan standar BR-1 serta minum ad libitum.

Tikus dibagi menjadi 4 kelompok secara acak yaitu 1 kelompok kontrol (K) dan 3 kelompok perlakuan (P1, P2, dan P3). Jumlah sampel minimal dihitung menggunakan rumus besar sampel eksperimental Federer yaitu $(\mathrm{t}-1)(\mathrm{n}-1) \geq 15$, dan didapatkan jumlah sampel minimal untuk tiap kelompok adalah 6 ekor. Namun, masing-masing kelompok dalam penelitian ini terdiri dari 7 ekor tikus untuk mengantisipasi drop out sehingga keseluruhan sampel yang dibutuhkan adalah 28 ekor.

Terdapat tiga jenis pakan yang diberikan yaitu pakan standar, pakan hiperkolesterol, dan pakan perlakuan yang terdiri dari pakan hiperkolesterol disertai sonde buah pepaya berbagai dosis. Pakan standar dan pakan hiperkolesterol diberikan 20 gram per hari dan air minum secara ad libitum. Pakan hiperkolesterol terdiri dari campuran 10\% telur puyuh dengan pakan standar yang dicampur secara homogen, dibentuk pelet, dan dikeringkan. Sisa pakan ditimbang dan dicatat setiap hari.

Buah pepaya yang digunakan adalah buah pepaya matang varietas California (IPB-9) umur 79 bulan yang didapat dari petani pepaya di Desa Menoreh, Kecamatan Salaman, Kabupaten Magelang. Buah pepaya dikupas kulit, dipisahkan 
bijinya, dicuci kemudian ditimbang dengan alat timbangan dengan ketelitian 0,1 gram. Buah pepaya dihaluskan, kemudian diblender tanpa penambahan air dan diberikan melalui sonde. Selang waktu antar sonde 3 jam dan jarak waktu antara pengupasan dengan pemberian buah pepaya maksimal 10 menit. Pemberian sonde dilakukan 2 kali sehari dengan masing-masing pemberian adalah separuh dari dosis karena kapasitas lambung tikus yang kecil $(5 \mathrm{ml})$. Dosis yang diberikan 5,4 gr (P1), 7,2 gr (P2), dan 9 gr (P3) per hari. Pemberian dosis ini berdasarkan pada anjuran konsumsi buah untuk manusia dalam upaya pencegahan penyakit jantung yaitu $3-5$ penukar/hari. ${ }^{2,4}$ Dosis tersebut kemudian dikonversi menjadi dosis untuk hewan coba.

Kadar kolesterol LDL dan kolesterol HDL awal diperiksa setelah 1 minggu pemberian pakan standar dan dilakukan pada 12 ekor tikus yang dipilih secara acak. Kadar kolesterol LDL dan kolesterol HDL hiperkolesterolemia diperiksa setelah 4 minggu pemberian pakan hiperkolesterol pada semua tikus. Begitu juga dengan kadar kolesterol LDL dan kolesterol HDL akhir diperiksa setelah 4 minggu pemberian pakan perlakuan.
Sampel darah tikus diambil sebanyak $2 \mathrm{ml}$ melalui pleksus retroorbitalis setelah tikus dipuasakan selama 12 jam sebelumnya. Kadar kolesterol LDL diperiksa dengan metode direk menggunakan reagen $L D L-C$ Select (DiaSys) dan diukur pada panjang gelombang $550 \mathrm{~nm}$. Kadar kolesterol HDL ditentukan dengan metode CHOP-PAP.

Data yang diperoleh diuji normalitasnya dengan uji Shapiro-Wilk. Perbedaan kadar kolesterol LDL dan kolesterol HDL sebelum dan setelah perlakuan diuji dengan paired t-test. Perbedaan pengaruh buah pepaya terhadap kadar kolesterol LDL dan HDL keempat kelompok dianalisis menggunakan uji One Way Anova yang dilanjutkan analisis post-hoc LSD. Masing-masing uji memiliki derajat kemaknaan $95 \% .^{14}$

\section{HASIL PENELITIAN}

Dua puluh delapan tikus Sprague Dawley jantan dipelihara menggunakan kandang individual. Sisa pakan dimonitor setiap hari dengan melakukan penimbangan untuk mengetahui konsumsi pakan tikus per hari. Gambaran konsumsi pakan tikus setiap hari dapat dilihat pada tabel 1.

Tabel 1. Rerata Konsumsi Pakan Harian saat Hiperkolesterolemia dan Selama Perlakuan

\begin{tabular}{|c|c|c|c|c|c|}
\hline \multirow{2}{*}{ Kelompok } & \multicolumn{2}{|c|}{ Konsumsi pakan (gr/hari) } & \multirow{2}{*}{$\begin{array}{c}\Delta \\
(\mathrm{mg} / \mathrm{dl})\end{array}$} & \multirow{2}{*}{$\begin{array}{l}\Delta \\
\%\end{array}$} & \multirow{2}{*}{$\mathrm{P}$} \\
\hline & Hiperkolesterolemia & Selama perlakuan & & & \\
\hline $\mathrm{K}$ & $15.09 \pm 2.13$ & $19,04 \pm 0,79$ & 3.95 & 26,18 & $0,018 *^{2}$ \\
\hline $\mathrm{P} 1$ & $13.95 \pm 1.58$ & $13,24 \pm 2,20$ & 0,71 & 5,09 & 0.524 \\
\hline $\mathrm{P} 2$ & $16.32 \pm 1.79$ & $13,85 \pm 3,23$ & 2.47 & 15,13 & 0.060 \\
\hline P3 & $14.86 \pm 1.86$ & $14,25 \pm 3,04$ & 0,61 & 4,10 & 0.614 \\
\hline
\end{tabular}

*memiliki perbedaan yang bermakna $(p<0,05)$

a menggunakan uji Wilcoxon

Berdasarkan data tabel 1, terlihat bahwa konsumsi pakan harian sebelum dan selama pemberian buah pepaya antar kelompok perlakuan tidak memiliki perbedaan secara bermakna $(p>0,05)$. Sedangkan pada kelompok kontrol terdapat perbedaan yang bermakna dimana terdapat peningkatan rata-rata konsumsi pakan harian sebesar 26,18\% ( $p<0,05)$.
Kadar Kolesterol Total, Kolesterol LDL dan Kolesterol HDL Sebelum dan Setelah Pemberian Pakan Hiperkolesterol

Penelitian ini menggunakan telur puyuh untuk menginduksi hiperkolesterolemia. Gambaran perubahan kadar kolesterol total, kolesterol LDL dan kolesterol HDL tersaji pada Tabel 2.

Tabel 3. Perbedaan kadar kolesterol LDL dan kolesterol HDL sebelum dan setelah pemberian pakan hiperkolesterol

\begin{tabular}{cccccc}
\hline \multirow{2}{*}{ Variabel } & \multicolumn{2}{c}{ Rerata $(\mathrm{mg} / \mathrm{dl})$} & $\Delta$ & $\Delta$ & \multirow{2}{*}{$\mathrm{P}$} \\
\cline { 2 - 3 }$(\mathrm{mg} / \mathrm{dl})$ & Sebelum & Setelah & $\%$ & \\
\hline Kolesterol Total & $45,42 \pm 8,68$ & $70,80 \pm 9,83$ & 25,08 & 55,21 & $0,00^{*}$ \\
Kolesterol LDL & $25,17 \pm 6,01$ & $38,17 \pm 9,74$ & 13,00 & 52,00 & $0,00^{*}$
\end{tabular}




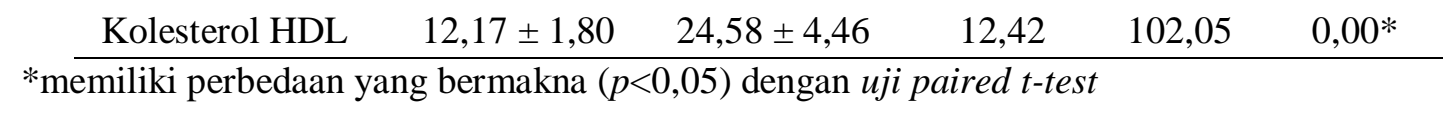

Berdasarkan data pada tabel 2, pemberian pakan hiperkolesterol selama 4 minggu menyebabkan peningkatan kadar kolesterol total, kolesterol LDL dan kolesterol HDL tikus secara bermakna $(p<0,001)$. Peningkatan berturut-turut sebanyak 25,08 mg/dl, $13.00 \mathrm{mg} / \mathrm{dl}$ dan 12,42 $\mathrm{mg} / \mathrm{dl}$ atau sebesar $55,21 \%, 52 \%$, dan 102,05\%.

\section{Kadar Kolesterol LDL Sebelum dan Setelah Pemberian Buah Pepaya}

Kadar kolesterol LDL pada keempat kelompok diukur setelah 4 minggu pemberian perlakuan. Gambaran perubahan kadar kolesterol LDL tiap kelompok ditunjukkan pada tabel 4.

Tabel 4. Perbedaan kadar kolesterol LDL sebelum dan setelah pemberian buah pepaya antar kelompok perlakuan

\begin{tabular}{|c|c|c|c|c|c|}
\hline \multirow{2}{*}{ Kelompok } & \multicolumn{2}{|c|}{ Rerata kadar kolesterol LDL (mg/dl) } & \multirow{2}{*}{$\begin{array}{c}\Delta \\
(\mathrm{mg} / \mathrm{dl})\end{array}$} & \multirow{2}{*}{$\begin{array}{l}\Delta \\
\%\end{array}$} & \multirow{2}{*}{$\mathrm{P}$} \\
\hline & Sebelum & Setelah & & & \\
\hline K & $48,14 \pm 11,59$ & $45,00 \pm 16,82^{\mathrm{a}}$ & 4,86 & 10,09 & 0.517 \\
\hline $\mathrm{P} 1$ & $45,29 \pm 9,05$ & $30,29 \pm 5,31^{\mathrm{b}}$ & 15,00 & 33,12 & $0.000 *$ \\
\hline $\mathrm{P} 2$ & $35,57 \pm 6,45$ & $31,00 \pm 8,12^{\mathrm{a}}$ & 4,57 & 12,85 & 0.137 \\
\hline $\mathrm{P} 3$ & $32,57 \pm 7,64$ & $33,43 \pm 6,85^{\mathrm{a}}$ & 0,86 & 2,64 & 0,804 \\
\hline
\end{tabular}

* memiliki perbedaan yang bermakna $(p<0,05)$ dengan uji paired $t$-test

${ }^{\mathrm{a}, \mathrm{b}}$ superskrip yang berbeda pada kolom sama, berbeda bermakna $(p<0,05)$

Data pada tabel 3 menunjukkan adanya penurunan kadar kolesterol LDL kelompok P1 dan P2. Penurunan kadar kolesterol LDL paling bermakna $(p<0,001)$ terjadi pada kelompok P1 sebanyak $15 \mathrm{mg} / \mathrm{dl}$ atau sekitar 33,12 \%. Kelompok P2 juga mengalami penurunan kadar kolesterol LDL sebanyak 4,57 mg/dl, sedangkan pada kelompok P3 terjadi peningkatan $0,86 \mathrm{mg} / \mathrm{dl}$. Namun, perubahan kadar kolesterol LDL pada kelompok P2 dan P3 tidak bermakna.

Data hasil uji One Way Anova menunjukkan adanya perubahan kadar kolesterol total LDL yang bermakna $(p<0,05)$ setelah pemberian buah pepaya selama 4 minggu dan penurunan paling bermakna bedasarkan uji post-hoc LSD terjadi pada kelompok P1 yang mendapat dosis 5,4 gr/hari.

\section{Kadar Kolesterol HDL Sebelum dan Setelah Pemberian Buah Pepaya}

Seperti pada pengukuran kadar kolesterol LDL, kadar kolesterol HDL pada keempat kelompok diukur setelah 4 minggu pemberian perlakuan. Gambaran perubahan kadar kolesterol HDL tiap kelompok ditunjukkan pada tabel berikut.

Tabel 5. Perbedaan kadar kolesterol HDL sebelum dan setelah pemberian buah pepaya antar kelompok perlakuan

\begin{tabular}{cccccc}
\hline \multirow{2}{*}{ Kelompok } & \multicolumn{2}{c}{ Rerata kadar kolesterol HDL } & \multirow{2}{c}{$\begin{array}{c}\Delta \\
(\mathrm{mg} / \mathrm{dl})\end{array}$} & $\begin{array}{c}\Delta \\
\%\end{array}$ & $\mathrm{P}$ \\
\cline { 2 - 3 } & Sebelum & Setelah & & & \\
\hline K & $29,00 \pm 3,16$ & $24,14 \pm 4,22$ & 4.86 & 16,76 & 0.402 \\
P1 & $25,71 \pm 5,09$ & $25,57 \pm 3,59$ & 0.14 & 0,56 & 0.930 \\
P2 & $26,29 \pm 4,23$ & $26,71 \pm 1,97$ & 0,42 & 1,59 & 0.205 \\
P3 & $23,43 \pm 5,83$ & $23,43 \pm 3,78$ & 0,00 & 0,00 & 1,000 \\
\hline
\end{tabular}

Data pada tabel 4 tidak menunjukkan adanya perbedaan kadar kolesterol HDL yang bermakna pada kelompok kontrol dan kelompok perlakuan sebelum dan setelah pemberian buah pepaya. Kadar kolesterol HDL kelompok kontrol dan P1 masing-masing mengalami penurunan $16,76 \%$ dan 0,56\%, kelompok P2 meningkat 17,38\%, sedangkan kadar kolesterol HDL kelompok P3 tetap. Namun, perbedaan kadar kolesterol HDL 
keempat kelompok tersebut tidak bermakna $(p>0,05)$.

Berdasarkan hasil uji One Way Anova, tidak terdapat perubahan kolesterol HDL yang bermakna sebelum dan setelah pemberian buah pepaya antar keempat kelompok kontrol dengan kelompok perlakuan yang mendapat buah pepaya $(p>0,05)$. Hal ini menunjukkan bahwa pemberian buah pepaya dosis $5,4 \mathrm{gr}, 7,2 \mathrm{gr}$, dan 9,0 gr tidak berpengaruh bermakna terhadap kadar kolesterol HDL.

\section{PEMBAHASAN}

Kadar Kolesterol Total, Kolesterol LDL dan Kolesterol HDL Sebelum - Setelah Pemberian Pakan Hiperkolesterol

Pemberian pakan hiperkolesterol pada semua kelompok memberikan pengaruh pada kadar kolesterol total, kolesterol LDL, dan kolesterol HDL. Setelah pemberian pakan hiperkolesterol selama 4 minggu, kadar kolesterol total, kolesterol LDL, dan kolesterol HDL meningkat 55,21\%, 52 $\%$ dan $102,05 \%$.

Peningkatan kadar kolesterol total dan kolesterol LDL mungkin dipengaruhi kandungan kolesterol dan asam lemak jenuh dalam telur puyuh yang menjadi campuran pakan kolesterol. Pada setiap 100 gr telur puyuh, terkandung 844 $\mathrm{mg} / \mathrm{dl}$ kolesterol dan 3,56 gr asam lemak jenuh. ${ }^{15}$ Asupan tinggi asam lemak jenuh dan kolesterol menyebabkan konsentrasi kolesterol meningkat karena kolesterol yang ada di dalam tubuh selain berasal dari asupan juga berasal dari sintesis oleh tubuh sendiri. Kandungan asam lemak jenuh meningkatkan kadar LDL melalui mekanisme penurunan sintesis dan aktivitas reseptor LDL. ${ }^{16}$ Pada sebuah penelitian yang meneliti asupan lemak jenuh, PUFA dan kolesterol terhadap respon kadar kolesterol, setiap asupan lemak jenuh $1 \%$ dari total energi sehari dapat meningkatkan $2,7 \mathrm{mg} / \mathrm{dl}$ kadar kolesterol. ${ }^{16}$

Peningkatan yang signifikan terjadi pada kadar kolesterol HDL dimana kadarnya meningkat $12,42 \mathrm{mg} / \mathrm{dl}$. Peningkatan mungkin disebabkan kandungan asam lemak tidak jenuh tunggal (MUFA) dalam telur puyuh. Dalam setiap 100 gram telur puyuh terkandung 4,33 gr MUFA, lebih banyak jika dibandingkan dengan kandungan asam lemak jenuh $\left(3,56\right.$ gr). ${ }^{16}$ Hal ini sesuai penelitian sebelumnya oleh OmniHeart Collaborative Research Group menunjukkan bahwa diit tinggi dapat MUFA meningkatkan kadar kolesterol HDL sebanyak $1,1 \mathrm{mg} / \mathrm{dl}$ secara bermakna. ${ }^{17}$

\section{Kadar Kolesterol LDL setelah Pemberian Buah Pepaya}

Berdasarkan hasil penelitian, pemberian buah pepaya kepada kelompok perlakuan selama 4 minggu memberikan pengaruh yang bermakna pada pemberian dengan dosis 5,4 gr/dl. Kadar kolesterol LDL mengalami penurunan 33,12\%.

Buah pepaya memiliki efek antihiperlipidemia melalui aktivitas berbagai macam senyawa biologis yang terkandung di dalamnya. Buah pepaya mengandung flavonoid, vitamin $\mathrm{C}$, niasin, dan serat. Pepaya mengandung flavonoid jenis quercetin sebanyak $2 \mathrm{mg} / 100 \mathrm{gr}$ yang berperan menghambat oksidasi LDL dan mencegah pembentukan radikal bebas. ${ }^{9,10}$ Pepaya matang diketahui mengandung vitamin $\mathrm{C}$ sekitar $61,8 \mathrm{mg} / 100$ gr yang dapat berperan sebagai antioksidan. ${ }^{8}$ Komposisi lipid pada kolesterol LDL terdapat kurang lebih 2600 molekul dimana separuhnya adalah asam lemak tak jenuh ganda (PUFA) yang sangat rentan terhadap oksidasi karena ikatan rangkapnya. Vitamin $\mathrm{C}$ sebagai antioksidan larut air paling efektif bekerja mencegah proses oksidasi lipid dalam plasma. Vitamin $\mathrm{C}$ mengikat vitamin $\mathrm{E}$ radikal yang terbentuk pada proses pemutusan reaksi radikal bebas dan meregenerasinya sehingga berfungsi kembali sebagai antioksidan. ${ }^{18}$ Selain itu, vitamin C membantu reaksi hidroksilasi dalam pembentukan asam empedu. Meningkatnya pembentukan asam empedu menyebabkan kolesterol sebagai bahan utama pembentuk asam ini banyak diambil dari dalam darah sehingga kadarnya dalam darah menurun. Penurunan kadar kolesterol kemudian ikut menurunkan kadar kolesterol LDL dalam tubuh. ${ }^{19,20}$

Kandungan niasin (vitamin $\mathrm{B}_{3}$ ) pada pepaya diketahui sebanyak $0,338 \mathrm{mg} / 100 \mathrm{gr}^{8}{ }^{8}$ Niasin dapat menghambat sekresi VLDL sehingga menurunkan produksi LDL. Niasin menurunkan mobilisasi asam lemak sehingga ikut menurunkan pembentukan VLDL. Menurunnya produksi VLDL menurunkan konversi VLDL menjadi kolesterol LDL. ${ }^{18}$

Kandungan lain dalam buah pepaya yang membantu menurunkan kadar kolesterol LDL adalah serat jenis pektin. ${ }^{11}$ Serat memperlambat pengosongan lambung serta mengikat asam empedu dan kolesterol di lumen usus untuk kemudian diekskresikan bersama feses. Bakteri dalam usus juga memfermentasikan serat dan menghasilkan asetat, propionat, dan butirat yang menghambat absorpsi kolesterol. Penurunan konsentrasi kolesterol akan menurunkan jumlah 
kilomikron remnan sehingga konversi VLDL menjadi LDL juga ikut menurun. ${ }^{41}$ Namun, penurunan kadar kolesterol LDL yang secara bermakna terjadi pada kelompok P1 tidak secara konsisten diikuti oleh kelompok P2 dan P3 sehingga dimungkinkan penurunan ini bukan disebabkan oleh buah pepaya melainkan berhubungan dengan hal teknis pemilihan hewan coba seperti umur dan kemurnian galur tikus serta manajemen lab termasuk pemeliharaan dan pemeriksaan darah yang tidak dapat sepenuhnya dikontrol oleh peneliti.

Penurunan kadar kolesterol LDL terlihat pada kelompok kontrol yang mendapat pakan tinggi lemak dan kolesterol. Hal ini mungkin dipengaruhi oleh tingkat stres pada kelompok kontrol yang lebih rendah dibandingkan dengan kelompok perlakuan. Kelompok kontrol tidak mendapatkan perlakuan sonde sedangkan ketiga kelompok perlakuan mendapatkan perlakuan sonde 2 kalo sehari. Frekuensi perlakuan yang didapatkan tikus (penyondean dan pembersihan kandang) dapat meningkatkan stres. Semakin banyaknya tikus mendapatkan perlakuan maka semakin tinggi tingkat stress yang dialami. ${ }^{21}$ Respon stres pada tikus dapat menyebabkan peningkatan kadar kolesterol yaitu terjadi peningkatan asam lemak bebas di dalam hati yang akan diubah menjadi VLDL yang bepengaruh terhadap peningkatan LDL di dalam aliran darah. ${ }^{21}$

Peningkatan kadar kolesterol LDL terjadi pada kelompok P3 yang mendapat pepaya dosis 9,0 gr/hari. Peningkatan ini mungkin dipengaruhi oleh asupan pakan tikus. Rata-rata konsumsi pakan kolesterol kelompok P3 selama perlakuan adalah $14,25 \pm 3,04 \mathrm{gr} / \mathrm{hari}$ dan rata-rata ini merupakan yang tertinggi dibandingkan kelompok perlakuan yang lain. Hal ini yang kemungkinan meningkatkan kadar kolesterol LDL kelompok P3 meskipun mendapatkan buah pepaya dengan dosis terbesar.

\section{Kadar Kolesterol HDL setelah Pemberian Buah Pepaya}

Pada ketiga kelompok perlakuan yang mendapat buah pepaya dalam dosis $5,4 \mathrm{gr}, 7,2 \mathrm{gr}$, dan 9,0 gr tidak menunjukkan adanya perubahan kadar kolesterol HDL secara bermakna. Penurunan kadar kolesterol HDL terjadi pada kelompok kontrol sebesar $16,76 \%$ tetapi setelah diuji statistik penurunan tersebut tidak bermakna.

Buah pepaya mengandung flavonoid jenis quercetin yang diharapkan dapat meningkatkan kadar kolesterol HDL melalui mekanisme peningkatan produksi apolipoprotein A-1.10,11 Namun hal ini tidak tampak pada hasil penelitian yang menunjukkan bahwa pemberian buah pepaya belum memberikan pengaruh yang bermakna terhadap peningkatan kadar kolesterol HDL. Hal ini dimungkinkan karena kadar kolesterol HDL dalam serum lebih dipengaruhi oleh faktor genetik atau familial (sebesar 50\%) dan sisanya dipengaruhi oleh faktor lain. ${ }^{18}$ Hasil ini sesuai dengan penelitian sebelumnya dimana pemberian quercetin sebanyak $1 \mathrm{gr} / \mathrm{hari}$ selama 28 hari tidak bermakna dalam meningkatkan kadar kolesterol HDL. ${ }^{22}$

\section{KETERBATASAN PENELITIAN}

Keterbatasan penelitian ini adalah tidak ada uji kandungan gizi pakan kolesterol serta kandungan buah pepaya yang digunakan. Selain itu, hal teknis pemilihan hewan coba seperti umur dan kemurnian galur tikus serta manajemen lab termasuk pemeliharaan dan pemeriksaan darah tidak dapat sepenuhnya dikontrol oleh peneliti.

\section{SIMPULAN DAN SARAN}

Pepaya memiliki kemampuan untuk menurunkan kadar kolesterol LDL dan memingkatkan kadar kolesterol HDL melalui kandungan berbagai senyawa biologis di dalamnya seperti quercetin, vitamn $\mathrm{C}$, niasin, dan serat larut air jenis pektin. Namun, pada penelitian ini hal tersebut tidak terbukti karena tidak terjadi penurunan kadar kolesterol LDL maupun peningkatan kadar kolesterol HDL yang konsisten antar kelompok perlakuan. Oleh karena itu, disimpulkan bahwa pemberian buah pepaya dosis 5,4 gr, 7,2 gr, dan 9 gr tidak dapat menurunkan kadar kolesterol LDL dan meningkatkan kadar kolesterol HDL pada tikus hiperkolesterolemia.

Perlu pengkajian lebih lanjut terkait pengaruh buah pepaya terhadap kadar koelsterol HDL yang merupakan faktor protektif penyakit kardiovaskuler.

\section{DAFTAR PUSTAKA}

1. WHO. Cardiovascular diseases [Online]. 2011. [cited 2012 feb 29]; Available from: URL: http://www.who.int/mediacentre/factsheets/fs $317 / \mathrm{e}$ n/index.html

2. Departemen Kesehatan. Pedoman pengendalian penyakit jantung dan pmbuluh darah. Jakarta: Bakti Husada; 2009.

3. American Heart Association. Third Report of the National Cholesterol Education Program (NCEP) Expert Panel on Detection, and Treatment of High 
Blood Cholesterol in Adult (Adult Treatment Panel III), 2001. Circulation 17/24, 2002.

4. Krummel DA. Medical nutrition therapy in cardiovascular disease. In: Mahan LK, EscottStump S. Krause's food, nutrition \& diet theraphy. 11th edition. Philadelphia: Saunders;2004.p.86082.

5. Boris H, Catherine N, Florent L, Francoise T, Taous L, Yves D et al. Effect of low-fat, fermented milk enriched with plant sterols on serum lipid profile and oxidative stress in moderate hypercholesterolemia. Am J Clin Nutr 2007;86:790-6.

6. Aryamitra B, Rakesh V, Neeta S, Harish P, Manish N., Anti-hyperlipidemic of Carica papaya L. in Sprague dawley rats. Nig. J. Prod. and Med 2006;10:69-72.

7. Aysun O, Hamide G, Esma G, Ayşe E. Antioxidant capacity of juice from different papaya (Carica papaya L.) cultivars grown under greenhouse conditions in Turkey. Turk $\mathrm{J}$ Biol 2011;35:619-25.

8. Wall MW. Ascorbic acid, vitamin A, and mineral composition of banana (Musa sp.) and papaya (Carica papaya) cultivars grown in Hawaii. Journal of Food Composition and Analysis 2006;19:43445.

9. Krishna KI, Paridhavi M, Patel JA. Review on nutritional, medicinal, and pharmacological properties of papaya (Carica papaya L.). Natural Product Radiance 2008;7:364-73.

10. Ngozi AI, George OG, Veronica IO, Sunday A, Tomi DE, Bola $\mathrm{O}$ et al. Phytochemical and antioxidant nutrient constituents of Carica papaya and Parquetina nigrescens extracts. Scientific Research and Essays 2010;5:2201-5.

11. Parle M, Gurditta. Basketfull benefits of papaya. IRJP 2011;2:6-12.

12. Anna HT, Saptawati B, Indriati PH. The effect of indigestible dextrin and phytosterol on serum LDL-cholesterol level on hypercholesterolemic subjects. Med J Indones 2009; 18: 114-9.

13. Kantham S, Tharun KG, Vasu K, Raja RR, Murthy JSN. Antihyperlipidemic activity of Carica papaya Linn extract in rats. Scientific Journal of Pharmacy 2011; 1(1): 16-8.

14. Dahlan MS. Statistik untuk kedokteran dan kesehatan. 5th ed. Jakarta: Salemba Medika; 2011. p. 47-112.

15. USDA National Nutrient Database for Standard Reference Release 24. [Online]. 2012. [cited 2012 Jul 31]; Available from:URL: http://ndb.nal.usda.gov/ndb/foods/show/128?qlook up=Egg $\% 2 \mathrm{C}+$ quail $\% 2 \mathrm{C}+$ whole $\% 2 \mathrm{C}+$ fresh $\% 2 \mathrm{C}+\mathrm{r}$ aw $\& \mathrm{f}=\&$ format $=\& \mathrm{mn}=\&$ facet $=\& \max =25 \&$ new $1 . \mathrm{h}$ $\underline{\mathrm{tml}}$

16. Botham KM, Mayes PA. Pengangkutan dan penyimpanan lipid. In: Murray RK, Granner DK, Rodwell VW, editors. Biokimia Harper. 27th ed. Jakarta: Penerbit Buku Kedokteran EGC; 2006. p.225-30.

17. Appel LJ, Sacks FM, Carey VJ, Obarzanek E, Swain JF, Miller ER et al. Effects of protein, monounsaturated fat, and carbohydrate intake on serum lipids: results of the OmniHeart randomized trial. JAMA 2005;19:2455-64.

18. Kirkland JB. Niacin. In: Zempleni J, Rucker RB, McCormick DB, Suttie JW, editors. Handbook of vitamin. 4th edition. Boca Ratan: Taylor \& Francis;2007.p.221.

19. Peter L, Masanori A. Vitamin C, collagen, and cracks in the plaque. Circulation 2002;105:1396-8.

20. Prakoso Z. Pengaruh pemberian vitamin C terhadap kadar LDL dan HDL kolesterol serum tikus wistar jantan hiperlipidemia setelah perlakuan jus lidah buaya (Aloe vera L.) [karya tulis ilmiah]. Semarang: Universitas Diponegoro; 2006.

21. Balcombe JP, Barnard DN, Sandusky C. Laboratory Routine Cause Animal Stress. American Association for Laboratory Animal Science. 2004;43.

22. Conquer JA, Maiani G, Azzini E, Raguzzini A, Holub BJ. Supplementation with Quercetin Markedly Increase Plasma Quercetin Concentration without Effect on Selected Risk Factors for Heart Disease in Healthy Subjects. Am J Clin Nutr 2008;22:593-97. 